\title{
CULTIVAR AND FOLIAR FEEDING OF PLANTS AS FACTORS DETERMINING THE CHEMICAL COMPOSITION OF SPELT (TRITICUM AESTIVUM SSP. SPELTA L.) GRAIN
}

\author{
ANDRUSZCZAK, S. $.^{*}-$ KRASKA, P. ${ }^{1}-$ KWIECIŃSKA-POPPE, E. ${ }^{1}-$ SKOWROŃSKA, M. ${ }^{2}$ \\ ${ }^{1}$ University of Life Sciences in Lublin, Department of Herbology and Plant Cultivation \\ Techniques, Institute of Agricultural Ecology, Akademicka 13, 20-950 Lublin, Poland \\ ${ }^{2}$ University of Life Sciences in Lublin, Department of Agricultural and Environmental \\ Chemistry, Akademicka 15, Lublin, Poland \\ ${ }^{*}$ Corresponding author \\ e-mail: sylwia.andruszczak@up.lublin.pl; phone: +48-81-445-6687 \\ (Received $11^{\text {th }}$ Nov 2019; accepted $12^{\text {th }}$ Feb 2020)
}

\begin{abstract}
Due to the constantly increasing interest in growing spelt, research on the effects of different agronomic factors on grain quantity and quality is still valid and necessary. Nevertheless, the available literature lacks comprehensive studies on optimization of spelt mineral fertilization, especially concerning grain chemical composition. The aim of this study was to evaluate some grain quality characteristics and macro- and micronutrient content in grain of winter spelt cultivars ('Oberkulmer Rotkorn', 'Badengold', 'Frankenkorn') depending on foliar fertilizers applied (Santaura Pro+ or Prohorti Micro Amin Mg). Fertilizers were applied three times during the spelt growing season. The chemical composition of spelt grain was mostly dependent on cultivar and weather conditions during the crop growing season. The highest $\mathrm{N}, \mathrm{Ca}, \mathrm{Mn}, \mathrm{Fe}$, and $\mathrm{Zn}$ contents were determined in grain of the cultivar 'Oberkulmer Rotkorn'. Moreover, this cultivar contained most protein and gluten and was characterized by the highest sedimentation index. Grain of cv. 'Badengold', in turn, was poorest in terms of protein and gluten and, at the same time, exhibited the lowest N, P, Mg, Ca, Mn, Fe, and Zn content. Application of foliar fertilizers increased N, P, K, Cu and $\mathrm{Mn}$ content in spelt grain compared to plants grown without foliar fertilization.
\end{abstract}

Keywords: macro- and micronutrients, protein, gluten, sedimentation index, biofortification

\section{Introduction}

To reduce the dominant position of common wheat as a basic food material, a growing interest has been observed in the cultivation of ancient wheat forms in recent years. One of them is spelt wheat (Triticum aestivum ssp. spelta L.), belonging to the biological species T. aestivum L. Spelt played an important role in nutrition in old Europe, becoming the main bread cereal. With time, however, it lost its importance and its crop area gradually declined (Arzani and Ashraf, 2017). For some period of time, spelt was a forgotten cereal, but during the last 20 years its popularity has been growing. Spelt is valued due to its favorable chemical composition and high nutrient uptake (Ziegler et al., 2016). Its grain is particularly rich in some minerals and vitamins as well as in active biological substances with antioxidant properties (Suchowilska et al., 2012; Świeca et al., 2014; Andruszczak, 2017; Zrcková et al., 2019). According to some authors, it is characterized by a more favorable chemical composition compared to common wheat cultivars because it contains more protein, gluten, amino acids, dietary fiber, fat-soluble vitamins (A, D, and E), and unsaturated fatty acids (Ruibal-Mendieta et al., 2005; GomezBecerra et al., 2010; Escarnot et al., 2012; Jablonskyte-Rašče et al., 2013; Stępień et al., 2016). It has been proven that consumption of spelt wheat promotes a reduction in blood 
cholesterol, supports digestive system activity, and reduces the risk of diseases related to the formation of gallstones in the body (Abdel-Aal and Rabalski, 2008).

The cultivar factor plays a major role in determining the chemical composition of cereal grains. Habitat conditions are also of essential importance, whereas agronomic practices, fertilization in particular, have a smaller impact (Cazzato et al., 2013). In modern agriculture, a proper cereal fertilization strategy should include not only soil fertilization, but also foliar feeding of plants. Such treatment enables quick supply of macro- and micronutrients both in the case of their deficiency in soil and inhibited nutrient uptake by root system (Mikos-Szymańska et al., 2018). Foliar fertilizer application is particularly advisable during the period of critical nutrient requirement of cereals, i.e. at stem elongation stage. In the case of micronutrients, foliar fertilization can essentially meet plants' requirement for these nutrients (Bharti et al., 2013). An insufficient amount of micronutrients in a plant leads to its reduced resistance to adverse habitat conditions and, as a consequence, to a decrease in yield and deteriorated grain quality (Potarzycki and Grzebisz, 2009).

The present study hypothesized that foliar application of the compound fertilizers Santaura Pro+ and Prohorti Micro Amin Mg would improve macro- and micronutrient supply to plants and beneficially affect the processing quality of spelt wheat grain. The aim of this study was to determine mineral content and also protein, gluten, and starch content as well as sedimentation index in spelt wheat grain depending on cultivar and foliar plant feeding.

\section{Materials and methods}

\section{Field experiment and cultivation management}

A field experiment was conducted over the period 2015-2017 at the Bezek Experimental Farm located near the city of Chełm $\left(51^{\circ} 19^{\prime} \mathrm{N}, 23^{\circ} 25^{\prime}\right.$ E), Poland. The experiment was set up on Rendzic Phaeozem [WRB, 2006] derived from Cretaceous bedrock and with a texture of loam. It was characterized by alkaline $\mathrm{pH}$, and the content of minerals was as follows: $\mathrm{N}_{\text {total }}-3.05 \mathrm{~g} \mathrm{~kg}^{-1}, \mathrm{~K}-194.7 \mathrm{mg} \mathrm{kg}^{-1}, \mathrm{P}-406.4 \mathrm{mg} \mathrm{kg}^{-1}$, $\mathrm{Mg}-17.9 \mathrm{mg} \mathrm{kg}^{-1}, \mathrm{~S}_{-} \mathrm{SO}_{4}-4.1 \mathrm{mg} \mathrm{kg}^{-1}, \mathrm{Zn}-22.33 \mathrm{mg} \mathrm{kg}{ }^{-1}, \mathrm{Mn}-195.83 \mathrm{mg} \mathrm{kg}{ }^{-1}$, $\mathrm{Cu}-2.55 \mathrm{mg} \mathrm{kg}^{-1}, \mathrm{Fe}-176.76 \mathrm{mg} \mathrm{kg}^{-1}$. The content of $\mathrm{C}_{\text {org }}$ was $31.3 \mathrm{~g} \mathrm{~kg}^{-1}$.

A two-factor field experiment was established in a split-plot design in triplicate with a plot area up to $12 \mathrm{~m}^{2}$. The experimental design included three winter spelt wheat cultivars, i.e. 'Oberkulmer Rotkorn', 'Badengold', and 'Frankenkorn'. The second research factor was application of foliar fertilizers Santaura Pro+ (SDP - Société de Distribution et de Prestation, France) or Pro Horti Micro Amin Mg (Adob, Poland). The fertilizers were applied three times during the spelt growing season, i.e. at tillering (BBCH 23-25), stem elongation (BBCH 33-35), and heading (BBCH 53-55), at rates of $11 \mathrm{ha}^{-1}$ and $4 \mathrm{~kg} \mathrm{ha}^{-1}$, respectively. The fertilizers were dissolved in 3001 of water per hectare. The control treatment comprised plots without foliar fertilization. Santaura Pro+ is an organic fertilizer obtained from sea algae, which contains nitrogen in the organic form (8\%), potassium $\left(\mathrm{K}_{2} \mathrm{O} 3 \%\right)$, and micronutrients (iron, manganese, boron, zinc, copper), while its organic matter content is $20 \%$. Pro Horti Micro Amin Mg fertilizer includes the following components: total nitrogen $(2.0 \%)$, ammonium nitrogen $(2 \%)$, magnesium oxide $(20.0 \%)$, sulfur trioxide $(39.3 \%)$, boron $(0.05 \%)$, water soluble molybdenum (0.01\%), amino acids (5.0\%), IDHA (D,L-Aspartic acid, (N-1,2 dicarboxyethyl)- 
tetrasodium salt) chelated zinc $(0.1 \%)$, IDHA chelated copper $(0.05 \%)$, IDHA chelated iron $(0.15 \%)$ and IDHA chelated manganese $(0.2 \%)$.

The previous crop of spelt was oats. Spelt spikelets were sown at the beginning of October at an amount of $350 \mathrm{~kg}$ per hectare. The thousand kernel weight of spelt was $41 \mathrm{~g}$. Mineral fertilization was as follows (in $\mathrm{kg}$ of pure ingredient per hectare): N 60 (20+40); P 26.2; K 83. Phosphate and potassium fertilizers as well as $20 \mathrm{~kg} \mathrm{~N} \mathrm{ha}^{-1}$ were applied before sowing spelt. In spring, $40 \mathrm{~kg} \mathrm{~N} \mathrm{ha}^{-1}$ was applied at stem elongation stage (BBCH 32-34).

\section{Chemical analysis of spelt grain}

Grain for chemical analysis was harvested every year at fully ripe stage of spelt (BBCH 89) following the methodology used in experiments on cereals (Ostrowska et al., 1991). Spikelet samples were collected in triplicate in three randomly selected places on each plot, delineated by a $1 \mathrm{~m}$ x $0.5 \mathrm{~m}$ rectangular frame. After harvest, the collected spelt spikelets were threshed in a Wintersteiger LD 180 thresher. The following elements was determined: $\mathrm{N}$ (Kjeldahl method), $\mathrm{P}$ (spectrophotometrically), $\mathrm{K}$ and $\mathrm{Ca}$ (flame photometry), $\mathrm{Mg}, \mathrm{Cu}, \mathrm{Zn}, \mathrm{Mn}, \mathrm{Fe}$ (atomic absorption spectrometry (AAS)), and B (spectrophotometric curcumin method). The chemical analysis was carried out in an accredited laboratory (accreditation certificate No. AB 1375 issued by the Polish Centre for Accreditation), which meets the requirements of the PN-EN ISO/IEC 17025:2005 standard.

Grain total protein, gluten, and starch content as well as Zeleny sedimentation index were determined using an OmegAnalyzer $\mathrm{G}$ computer transmission analyzer of whole grain (Bruins Instruments, Germany).

\section{Statistical analysis}

The obtained results were statistically analyzed by analysis of variance. The means were compared using least significant differences based on Tukey's test $(\mathrm{P} \leq 0.05)$. Calculations were made using ARSTAT statistical software, developed at the Faculty of Applied Mathematics and Information Technology of the University of Life Sciences in Lublin.

\section{Weather conditions}

During the field experiment, the average air temperature was generally higher than the long-term average from $1.0^{\circ} \mathrm{C}$ in the 2016-2017 growing season to $2.2^{\circ} \mathrm{C}$ in the 2015-2016 season (Fig. 1). In the 2014-2015 season, the total rainfall was lower than the long-term average for the relevant period by $23 \%$, while the highest rainfall deficit was found during the period from September to November and also from July to August. The second year of the experiment was much wetter and in that year the total rainfall was higher than the long-term average by $31 \%$. The total rainfall during the 2016-2017 season was close to the long-term average, but the rainfall distribution during the crop growing season varied. The most moisture was recorded in October - in that month the total rainfall exceeded three times the long-term average. In June and August, in turn, a significant rainfall deficit was observed; compared to the long-term average, the amount of rainfall was lower by $65 \%$ and $44 \%$, respectively. 

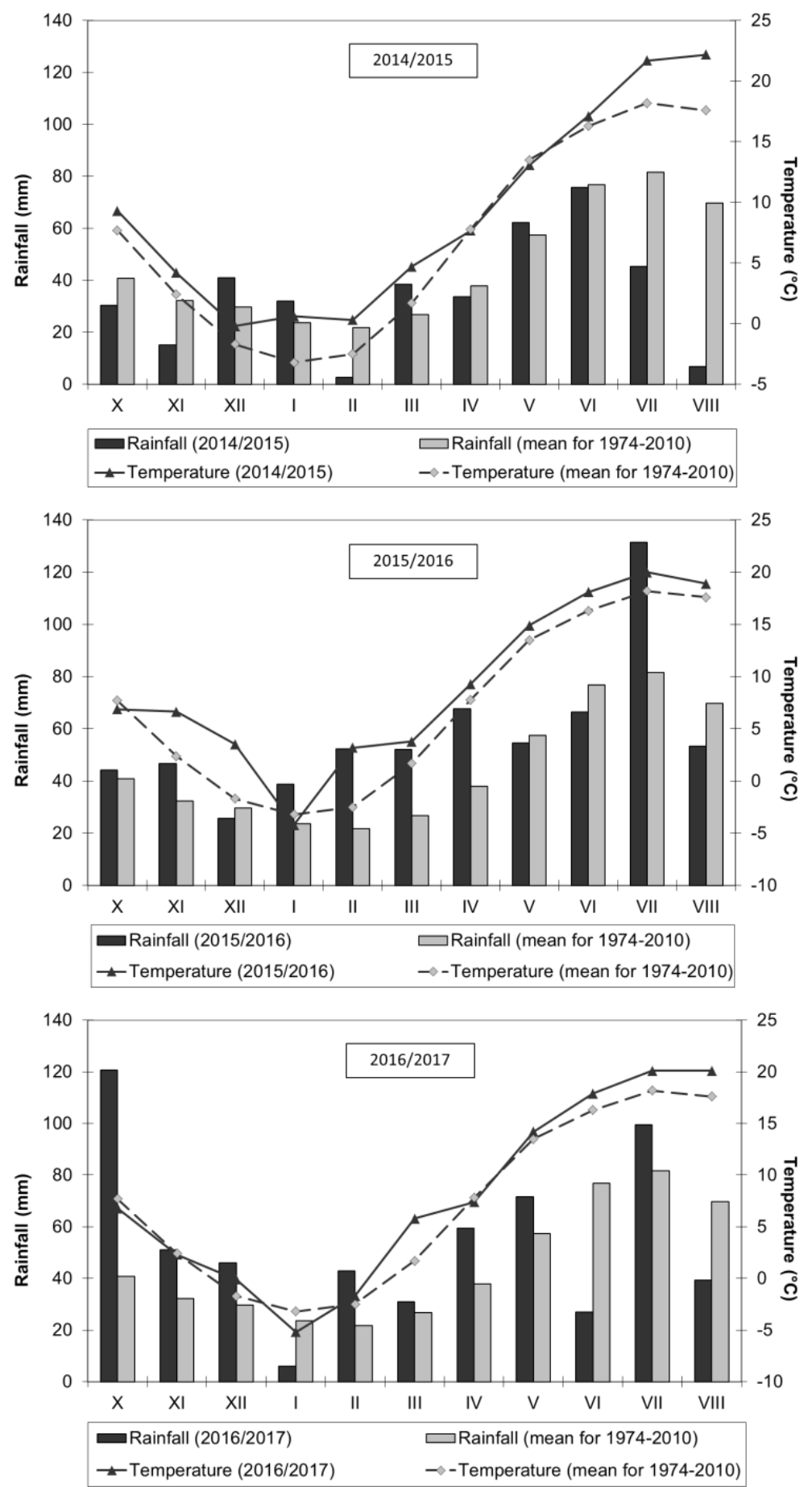

Figure 1. Weather conditions during the research compared to the long-term period

\section{Results and discussion}

This study shows that the genetic factor had a significantly differential effect on the contents of all macronutrients evaluated in spelt grain (Table 1). Among the cultivars studied, most $\mathrm{N}$ and $\mathrm{Ca}$ were found in grain of $\mathrm{cv}$. 'Oberkulmer Rotkorn'. $\mathrm{Cv}$. 'Frankenkorn' contained most $\mathrm{P}$ and $\mathrm{Mg}$, while cv. 'Badengold', in turn, was characterized by the highest $\mathrm{K}$ content. At the same time, grain of cv. 'Badengold' was 
found to have a significantly lower $\mathrm{N}, \mathrm{P}$, and $\mathrm{Ca}$ content in comparison to the other cultivars, whereas relative to cv. 'Frankenkorn' - a significantly lower Mg content. The obtained results corroborate the studies of other authors which indicate high variation in the mineral composition of spelt grain due to the genotype (Gomez-Becerra et al., 2010; Andruszczak, 2018; Kraska et al., 2019).

Table 1. The content of macroelements in spelt wheat grain depending on experimental factors $\left(g \mathrm{~kg}^{-1}\right)$

\begin{tabular}{c|c|c|c|c|c}
\hline Factor & $\mathbf{N}$ & $\mathbf{P}$ & $\mathbf{K}$ & $\mathbf{M g}$ & Ca \\
\hline Cultivars & & & & & \\
Oberkulmer R. (OR) & $24.44 \mathrm{a}^{*}$ & $3.937 \mathrm{a}$ & $3.295 \mathrm{a}$ & $1.184 \mathrm{ab}$ & $0.238 \mathrm{a}$ \\
Badengold (B) & $21.03 \mathrm{~b}$ & $3.768 \mathrm{~b}$ & $3.484 \mathrm{~b}$ & $1.132 \mathrm{a}$ & $0.203 \mathrm{~b}$ \\
Frankenkorn (F) & $23.25 \mathrm{c}$ & $4.019 \mathrm{c}$ & $2.766 \mathrm{c}$ & $1.250 \mathrm{~b}$ & $0.225 \mathrm{a}$ \\
\hline Foliar fertilizers & & & & & \\
Control object (K) & $22.71 \mathrm{a}$ & $3.826 \mathrm{a}$ & $3.103 \mathrm{a}$ & $1.169 \mathrm{a}$ & $0.219 \mathrm{a}$ \\
Santaura Pro+ (S) & $22.99 \mathrm{~b}$ & $3.994 \mathrm{~b}$ & $3.278 \mathrm{~b}$ & $1.194 \mathrm{a}$ & $0.221 \mathrm{a}$ \\
Prohorti Micro Amin Mg (P) & $23.03 \mathrm{~b}$ & $3.904 \mathrm{c}$ & $3.164 \mathrm{a}$ & $1.203 \mathrm{a}$ & $0.226 \mathrm{a}$ \\
\hline Years & & & & & \\
2015 & $22.07 \mathrm{a}$ & $3.874 \mathrm{a}$ & $3.162 \mathrm{a}$ & $1.619 \mathrm{a}$ & $0.308 \mathrm{a}$ \\
2016 & $27.27 \mathrm{~b}$ & $4.211 \mathrm{~b}$ & $2.993 \mathrm{~b}$ & $1.024 \mathrm{~b}$ & $0.189 \mathrm{~b}$ \\
2017 & $19.39 \mathrm{c}$ & $3.639 \mathrm{c}$ & $3.390 \mathrm{c}$ & $0.923 \mathrm{~b}$ & $0.168 \mathrm{~b}$ \\
\hline
\end{tabular}

* different letters indicate significant differences at $\mathrm{P} \leq 0.05$ )

Foliar feeding of plants did not have a significant effect on magnesium and calcium content in spelt grain. On the other hand, it resulted in a significant increase in nitrogen and phosphorus content compared to the control treatment. At the same time, this study demonstrated that spelt wheat fertilized with the fertilizer Prohorti Micro Amin Mg contained significantly less phosphorus and potassium in grain compared to plants fertilized with Santaura Pro+. Existing research shows different directions in changes in the chemical composition of cereal grains as influenced by foliar fertilization. Seadh et al. (2009) revealed a beneficial impact of foliar application of micronutrients on N, P, and K content in wheat grain. In turn, in a study by Majcherczak et al. (2006) foliar application of micronutrient fertilizer and copper caused a significant decrease in $\mathrm{K}$ content in spring barley grain, whereas zinc and manganese application reduced $\mathrm{P}$ concentration.

In the opinion of Kraska et al. (2013) and Gomez-Becerra et al. (2010), mineral content in spelt grain is significantly affected by habitat conditions, in particular weather conditions. This is confirmed by the present study which showed spelt wheat to exhibit high sensitivity to variable weather conditions during the study period. Spelt grain harvested in 2015 was characterized by a significantly higher $\mathrm{Mg}$ and $\mathrm{Ca}$ content compared to the other years. In the second year of the experiment, the highest grain $\mathrm{N}$ and $\mathrm{P}$ content and at the same time the lowest $\mathrm{K}$ content were obtained, whereas the pattern of weather conditions in 2017 was least favorable for macronutrient content. The then recorded rainfall deficit during spelt flowering and grain ripening, coupled with high air temperature, caused a significant decrease in $\mathrm{N}, \mathrm{P}, \mathrm{Mg}$, and $\mathrm{Ca}$ content in grain, whereas the amount of $\mathrm{K}$ increased.

Micronutrient content is an important characteristic from the point of view of the consumer and the nutritional value of a food material. Even though micronutrients are taken up by plants in small amounts, they perform important physiological functions, participating in many metabolic reactions occurring in plants (Potarzycki and Grzebisz, 
2009). The present study reveals that the cultivar factor caused significant differences in $\mathrm{Mn}, \mathrm{Zn}$, and $\mathrm{Fe}$ content in spelt grain, while $\mathrm{Cu}$ and $\mathrm{B}$ content showed small variations (Table 2). Most micronutrients were found in grain of cv. 'Oberkulmer Rotkorn', whereas cv. 'Badengold' grain was poorest in $\mathrm{Mn}, \mathrm{Fe}$, and $\mathrm{Zn}$. The obtained $\mathrm{Mn}$ and Fe contents in spelt grain did not substantially differ from the values found for the same cultivars by Kraska et al. (2013). However, these authors demonstrated a much higher $\mathrm{Cu}$ and $\mathrm{Zn}$ content in grain.

Table 2. The content of microelements in spelt wheat grain depending on experimental factors $\left(m g \mathrm{~kg}^{-1}\right)$

\begin{tabular}{c|c|c|c|c|c}
\hline Factor & Cu & Mn & Fe & Zn & B \\
\hline Cultivars & & & & & \\
Oberkulmer R. (OR) & $3.747 \mathrm{a}^{*}$ & $33.56 \mathrm{a}$ & $42.29 \mathrm{a}$ & $27.97 \mathrm{a}$ & $1.227 \mathrm{a}$ \\
Badengold (B) & $3.563 \mathrm{a}$ & $28.11 \mathrm{~b}$ & $31.57 \mathrm{~b}$ & $23.63 \mathrm{~b}$ & $1.246 \mathrm{a}$ \\
Frankenkorn (F) & $3.472 \mathrm{a}$ & $31.10 \mathrm{c}$ & $40.91 \mathrm{a}$ & $26.27 \mathrm{c}$ & $1.271 \mathrm{a}$ \\
\hline Foliar fertilizers & & & & & \\
Control object (K) & $3.391 \mathrm{a}$ & $30.11 \mathrm{a}$ & $37.49 \mathrm{a}$ & $25.51 \mathrm{a}$ & $1.223 \mathrm{a}$ \\
Santaura Pro+ (S) & $3.417 \mathrm{a}$ & $32.11 \mathrm{~b}$ & $38.16 \mathrm{a}$ & $26.47 \mathrm{a}$ & $1.247 \mathrm{a}$ \\
Prohorti Micro Amin Mg (P) & $3.973 \mathrm{~b}$ & $30.56 \mathrm{a}$ & $39.12 \mathrm{a}$ & $25.89 \mathrm{a}$ & $1.273 \mathrm{a}$ \\
\hline Years & & & & & \\
2015 & $3.408 \mathrm{a}$ & $48.23 \mathrm{a}$ & $39.92 \mathrm{a}$ & $23.74 \mathrm{a}$ & $1.251 \mathrm{a}$ \\
2016 & $2.662 \mathrm{~b}$ & $19.99 \mathrm{~b}$ & $39.54 \mathrm{a}$ & $26.39 \mathrm{~b}$ & $1.237 \mathrm{a}$ \\
2017 & $4.712 \mathrm{c}$ & $24.56 \mathrm{c}$ & $35.31 \mathrm{~b}$ & $27.74 \mathrm{c}$ & $1.256 \mathrm{a}$ \\
\hline
\end{tabular}

* different letters indicate significant differences at $\mathrm{P} \leq 0.05$ )

Application of the compound foliar fertilizers Santaura Pro+ and Prohorti Micro Amin $\mathrm{Mg}$, compared to the control treatment resulted in significant increase in $\mathrm{Mn}$ and $\mathrm{Cu}$ concentration in spelt grain, respectively. On the other hand, foliar fertilization did not affect Fe, Zn, and B content. In a study by Knapowski et al. (2017), foliar application of manganese and copper in the form of Adob $\mathrm{Mn}$ and Adob $\mathrm{Cu}$ fertilizers significantly increased the content of these elements in spelt grain, at the same time reducing $\mathrm{Zn}$ content. In turn, Wojtkowiak and Stępień (2015), who applied foliar fertilization of spelt wheat with copper, zinc, and manganese, found grain Fe, $\mathrm{Zn}$, and Mn content to increase.

Micronutrient content (except for B) in spelt grain was significantly affected by weather conditions, which was also confirmed by Gomez-Becerra et al. (2010) as well as by Wojtkowiak and Stępien (2015) in their studies. In the first year of the experiment, spelt grain was characterized by the highest $\mathrm{Mn}$ and Fe content, whereas significantly more $\mathrm{Cu}$ and $\mathrm{Zn}$ were found in grain harvested in 2017 compared to the other years.

Baking quality, which characterizes the suitability of flour for making bread products with appropriate quality characteristics, can be indirectly determined using processing quality parameters such as total protein and gluten content. The present study demonstrates that the spelt cultivars compared differed in terms of grain protein content, which ranged from $13.2 \%$ to $15.9 \%$. Cv. 'Oberkulmer Rotkorn' exhibited the significantly highest protein and gluten content, while cv. 'Badengold', in turn, was poorest in these components (Figures 2 and 3). Jablonskytė-Raščè et al. (2013) showed similar contents of this component in their research, while Wojtkowiak and Stępien (2015) determined protein content to range between $12.4 \%$ and $13.5 \%$. 


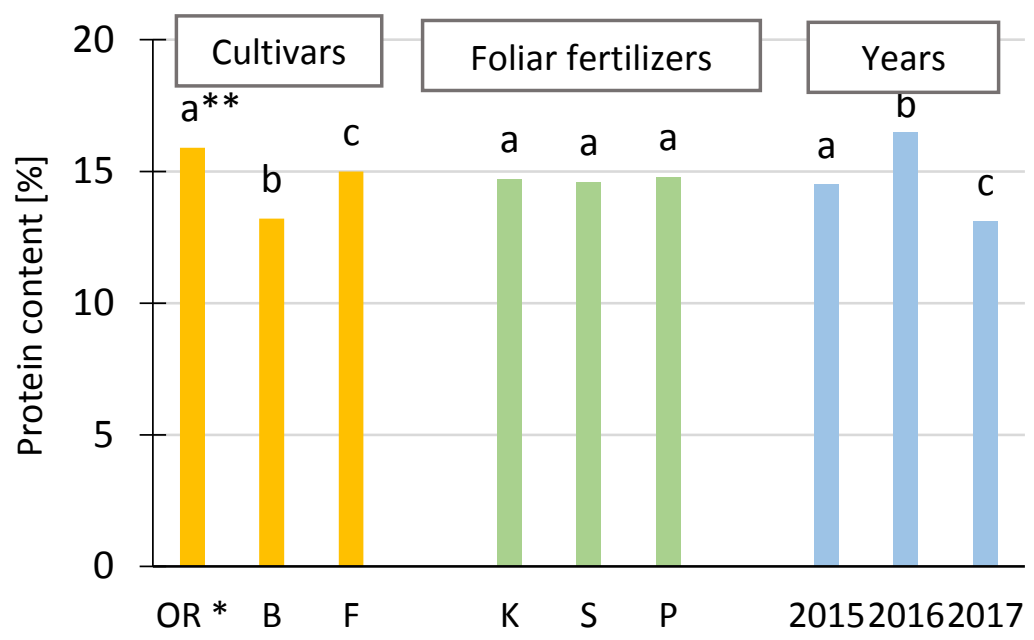

Figure 2. The protein content in spelt wheat grain depending on experimental factors $(* O R-$ Oberkulmer Rotkorn, $B$-Badengold, F-Frankenkorn, $K$ - control object without foliar fertilization, S-Santaura Pro+, P-Prohorti Micro Amin Mg; ** different letters indicate significant differences at $P \leq 0.05$ )

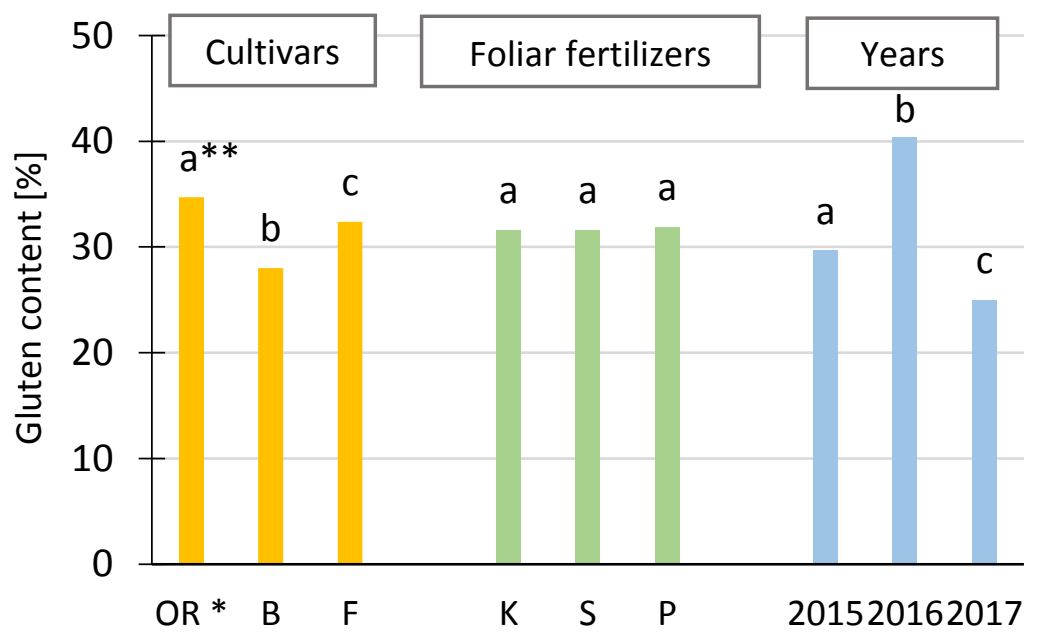

Figure 3. The gluten content in spelt wheat grain depending on experimental factors $(*$ OR Oberkulmer Rotkorn, $B$ - Badengold, $F$ - Frankenkorn, $K$ - control object without foliar fertilization, $S$-Santaura Pro+, P-Prohorti Micro Amin Mg; ** different letters indicate significant differences at $P \leq 0.05$ )

In a study on the winter spelt cultivar 'Rokosz', Knapowski et al. (2016) proved that foliar application of micronutrients has a beneficial effect on grain quality traits. This study did not confirm such a relationship. The protein and gluten content in spelt grain under application of the fertilizers Santaura Pro+ and Prohorti Micro Amin Mg and in the control treatment was similar. Significant differences were however found between years. Grain harvested in 2016 contained most protein and gluten, whereas the lowest contents of these components were shown in the last year of the study (Figures 2 and 3). 
Starch content in spelt grain was significantly dependent on cultivar and weather conditions during the growing season, but foliar fertilizer application did not result in significant differences in this trait (Figure 4).

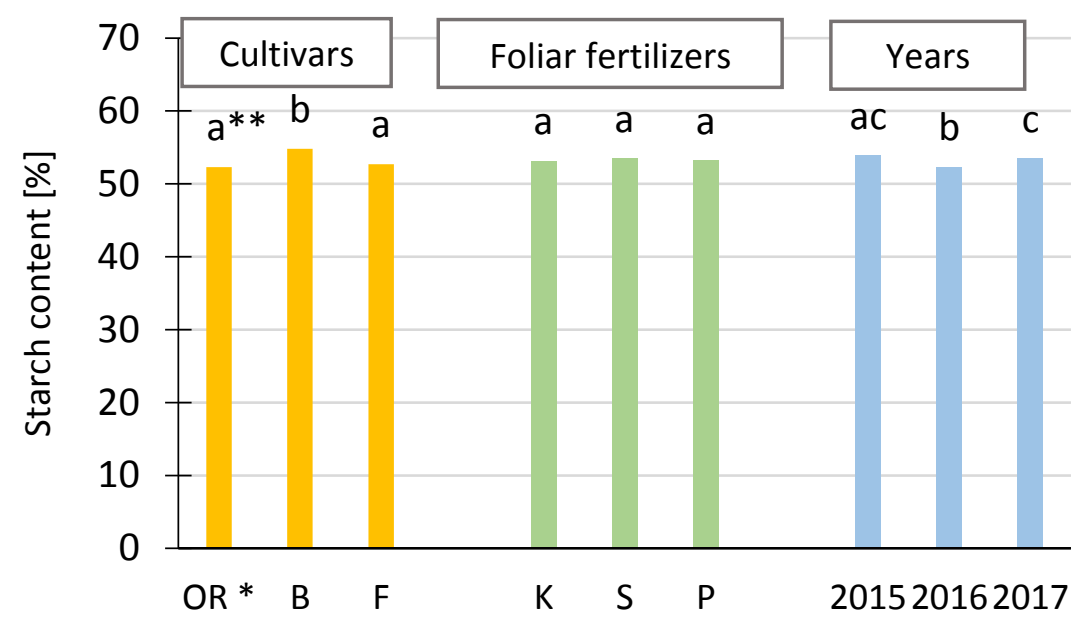

Figure 4. The starch content in spelt wheat grain depending on experimental factors $(*$ OR Oberkulmer Rotkorn, $B$ - Badengold, $F$ - Frankenkorn, $K$ - control object without foliar fertilization, $S$-Santaura Pro+, P-Prohorti Micro Amin Mg; ** different letters indicate significant differences at $P \leq 0.05$ )

Among the spelt cultivars in question, the highest sedimentation index was found in the case of cv. 'Oberkulmer Rotkorn', its value was significantly lower for $\mathrm{cv}$. 'Frankenkorn', whereas the lowest value of this index was obtained for cv. 'Badengold' (Figure 5). The experiment did not prove that application of the fertilizers Santaura Pro+ and Prohorti Micro Amin Mg had a significant effect on Zeleny sedimentation index, but this study found significant differences in the values of this index between years - the highest sedimentation value was obtained for grain harvested in 2016.

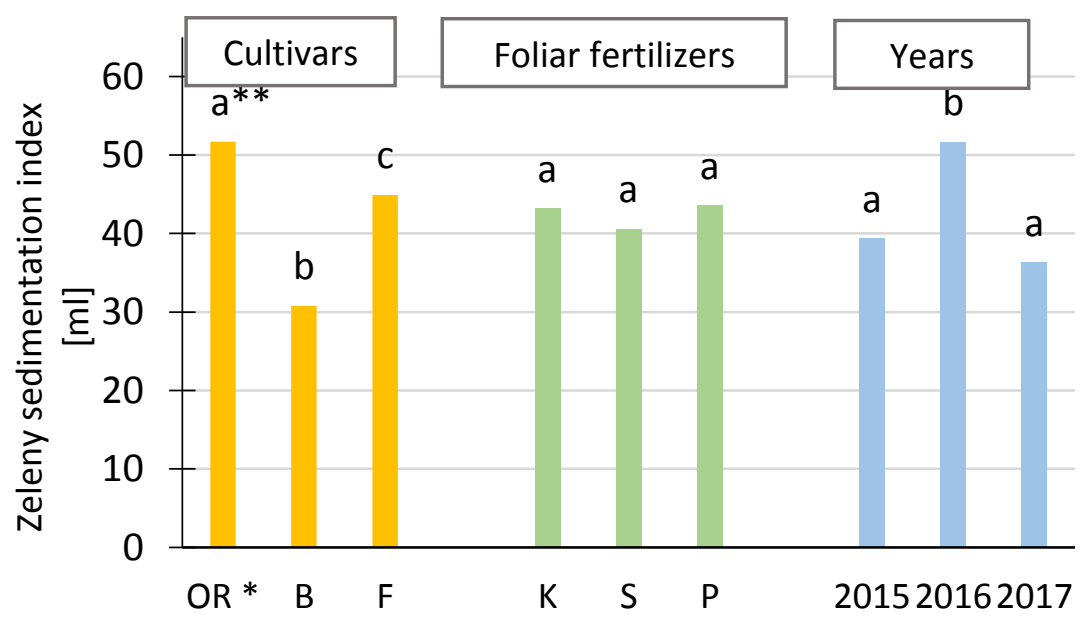

Figure 5. The Zeleny sedimentation index of spelt wheat grain depending on experimental factors (*OR-Oberkulmer Rotkorn, $B$-Badengold, $F$ - Frankenkorn, $K$ - control object without foliar fertilization, $S$-Santaura Pro+, P-Prohorti Micro Amin Mg; ** different letters indicate significant differences at $P \leq 0.05$ ) 


\section{Conclusions}

To sum up, it should be stated that the chemical composition of spelt grain was determined by the individual characteristics of a specific cultivar, weather conditions during the crop growing season, as well as foliar application of the fertilizers Santaura Pro+ and Prohorti Micro Amin Mg.

Most N, Ca, Mn, Fe, and Zn were found in grain of the cultivar 'Oberkulmer Rotkorn'. This cultivar was also distinguished by the highest protein and gluten content as well as the highest sedimentation index. In turn, grain of cv. 'Badengold' was characterized by the least favorable chemical composition since it contained the least $\mathrm{N}, \mathrm{P}, \mathrm{Mg}, \mathrm{Ca}, \mathrm{Mn}$, $\mathrm{Fe}$, and $\mathrm{Zn}$, and was also poorest in protein and gluten.

Application of foliar fertilizers significantly increased $\mathrm{N}$ and $\mathrm{P}$ content in spelt grain. In addition, Santaura Pro+ had a positive effect on the $\mathrm{K}$ and Mn content, while Prohorti Micro Amin Mg caused the increase in $\mathrm{Cu}$ content compared to spelt grown without foliar fertilization.

Due to the constantly growing interest in spelt cultivation, research on the effect of biofortification on grain quality is still valid and necessary. An interesting aspect, however, seems to be testing other foliar fertilizers to improve grain nutritional value. At the same time, it is worth considering more varieties of spelt in the study to draw more general conclusions.

Acknowledgements. This research was supported by the Ministry of Science and Higher Education in Poland.

\section{REFERENCES}

[1] Abdel-Aal, E. S. M., Rabalski, I. (2008): Bioactive compounds and their antioxidant capacity in selected primitive and modern wheat species. - The Open Agriculture Journal 2: 7-14.

[2] Andruszczak, S. (2017): Reaction of winter spelt cultivars to reduced tillage system and chemical plant protection. - Zemdirbyste-Agriculture 1: 15-22.

[3] Andruszczak, S. (2018): Spelt wheat grain yield and nutritional value response to sowing rate and nitrogen fertilization. - Journal of Animal and Plant Science 5: 1476-1484.

[4] Arzani, A., Ashraf, M. (2017): Cultivated ancient wheats (Triticum ssp.): a potential source of health-beneficial products. - Comprehensive Reviews in Food Science and Food Safety 16: 477-488.

[5] Bharti, K., Pandey, N., Shankhdhar, D., Srivastava, P. C., Shankhdhar, S. C. (2013): Improving nutritional quality of wheat through soil and foliar zinc application. - Plant, Soil and Environment 8: 348-352.

[6] Cazzato, E., Tufarelli, V., Laudadio, V., Stellacci, A. M., Selvaggi, M., Leoni, B., Troccoli, C. (2013): Forage yield and quality of emmer (Triticum dicoccum Schubler) and spelt (Triticum spelta L.) as affected by harvest period and nitrogen fertilization. - Acta Agriculturae Scandinavica, Section B: Soil and Plant Science 7: 571-578.

[7] Escarnot, E., Jacquemin, J. M., Agneessens, R., Paquot, M. (2012): Comparative study of the content and profiles of macronutrients in spelt and wheat (a review). - Biotechnology, Agronomy, Society and Environment (BASE) 16: 243-256.

[8] Gomez-Becerra, H. F., Erdemb, H., Yazici, A., Tutusa, Y., Torun, B., Ozturk, L., Cakmak, I. (2010): Grain concentrations of protein and mineral nutrients in a large collection of spelt wheat grown under different environments. - Journal of Cereal Science 3: 342-349. 
[9] Jablonskytè-Raščè, D., Maikštennienè, S., Mankevičienè, A. (2013): Evaluation of productivity and quality of common wheat (Triticum aestivum L.) and spelt (Triticum spelta L.) in relation to nutrition conditions. - Zemdirbyste-Agriculture 1: 45-55.

[10] Knapowski, T., Spychaj-Fabisiak, E., Kozera, W., Barczak, B., Murawska, B. (2016): Mineral fertilization and baking value of grain and flour of Triticum aestivum ssp. spelta L. - American Journal of Experimental Agriculture 4: 1-11.

[11] Knapowski, T., Kozera, W., Wszelaczyńska, E., Pobereżny, J., Cieślewicz, J., Chmielewski, J. (2017): The effect of environmental conditions on the content of selected micronutrients in spelt grain. - Environmental Protection and Natural Resources 3: 26-31.

[12] Kraska, P., Andruszczak, S., Kwiecińska-Poppe, E., Pałys, E. (2013): Effect of chemical crop protection on the content of some elements in grain of spelt wheat (Triticum aestivum ssp. spelta). - Journal of Elementology 1: 79-90.

[13] Kraska, P., Andruszczak, A., Dziki, D., Stocki, M., Stocka, N., Kwiecińska-Poppe, E., Różyło, K., Gierasimiuk, P. (2019): Green grain of spelt (Triticum aestivum ssp. spelta) harvested at the stage of milk-dough as a rich source of valuable nutrients. - Emirates Journal of Food and Agriculture 4: 263-270.

[14] Majcherczak, E., Kozera, W., Nowak, K., Barczak, B. (2006): The content of macroelements and ionic ratios in spring barley grain under foliar fertilization with microelements. - Journal of Elementology 1: 43-48. (in Polish).

[15] Mikos-Szymańska, M., Borowik, M., Wyzińska, M., Rusek, P. (2018): Effects of different fertilizer treatments on grain yield and yield components of spring wheat. - Research for Rural Development 2: 100-106.

[16] Ostrowska, A., Gawliński, S., Szczubiałka, Z. (1991): Methods of analysis and assessment of soil and plant properties. - Institute of Plant Protection, Warsow.

[17] Potarzycki, J., Grzebisz, W. (2009): Effect of zinc foliar application on grain yield of maize and its yielding components. - Plant, Soil and Environment 12: 519-527.

[18] Ruibal-Mendieta, N. L., Delacroix, D. L., Mignolet, J. M. P., Marques, C., Rozenberg, R., Petitjean, G., Habib-Jiwan, J. L., Meurens, M., Qeentin-Leclerco, J., Delzenne, N. M., Larondelle, Y. (2005): Spelt (Triticum aestivum ssp. spelta) as a source of breadmaking flours and bran naturally enriched in oleic acid and minerals but not phytic acid. - Journal of Agricultural and Food Chemistry 53: 2751-2759.

[19] Seadh, S. E., EL-Abady, M. I., El-Ghamry, A. M., Farouk, S. (2009): Influence of micronutrients foliar application and nitrogen fertilization on wheat yield and quality of grain and seed. - Journal of Biological Sciences 9: 851-858.

[20] Stępień, A., Wojtkowiak, K., Orzech, K., Wiktorski, A. (2016): Nutritional and technological characteristics of common and spelt wheats are affected by mineral fertilizer and organic stimulator Nano-Groß. - Acta Scientiarum Polonorum, Agricultura 15(2): 49-63.

[21] Suchowilska, E., Wiwart, M., Kandler, W., Krska, R. (2012): A comparison of macro- and microelement concentrations in whole grain of four Triticum species. - Plant, Soil and Environment 3: 141-147.

[22] Świeca, M., Dziki, D., Gawlik-Dziki, U., Różyło, R., Andruszczak, S., Kraska, P., Kowalczyk, D., Pałys, E., Baraniak, B. (2014): Grinding and nutritional properties of six spelt (Triticum aestivum ssp. spelta L.) cultivars. - Cereal Chemistry 3: 247-254.

[23] Wojtkowiak, K., Stępień, A. (2015): Nutritive value of spelt (Triticum aestivum spp. spelta L.) as influenced by the foliar application of copper, zinc and manganese. - ZemdirbysteAgriculture 4: 389-396.

[24] Ziegler, J. U., Schweiggert, R. M., Würschum, T., Longin, C. F. H., Carle, R. (2016): Lipophilic antioxidants in wheat (Triticum spp.): A target for breeding new varieties for future functional cereal products. - Journal of Functional Foods 20: 594-605.

[25] Zrcková, M., Capouchová, I., Paznocht, L., Eliášová, M., Dvořák, P., Konvalina, P., Janovská, D., Orsák, M., Bečková, L. (2019): Variation of the total content of polyphenols and phenolic acids in einkorn, emmer, spelt and common wheat grain as a function of genotype, wheat species and crop year. - Plant, Soil and Environment 5: 260-266. 